\title{
PERANAN SIDIK JARI DALAM PROSES PENYIDIKAN UNTUK MENENTUKAN PELAKU TINDAK PIDANA*
}

\author{
ANNY YUSERLINA \\ Sekolah Tinggi Ilmu Hukum Putri Maharaja \\ Jl.Inai Belakang SPBU Koto Nan IV Payakumbuh \\ email: annyyuserlina@hotmail.com
}

\begin{abstract}
Taking the latent fingerprints is present on the objects at the scene of the case, after which the object is held or tramped can be done in two ways, namely through puder and chemical process. Besides, fingerprint can also be done at the Investigation Office against suspects and people who want to take care of the letters, such as SKKB. In this case fingerprint is performed on a rolled impression and plain impression columns and columns for information along with the identity of the person whose fingerprints are taken. In the case of the perpetrator or suspect of a crime not yet caught, the fingerprint is one of the objective physical proofs in recognizing the return and identification of its behavior by comparing fingerprints between suspected persons or fingerprints that have been stored in police files with latent fingerprints found from crime scenes (TKP). it uses the empirical yuidist method which is empirical juridical itself according to Fred N Kerlner: as the questions tried to find the answer. It can be concluded that the authors want to approach the role of fingerprints in the investigation process tub from juridical aspect (legislation) maupundalam aspect $p$ the implementation of the community (police). So in conclusion the latent fingerprint is found on the objects at the scene of the case, after the object is held or tramped can be done in two ways, namely through puder and chemical process. Besides, fingerprint can also be done at the Investigation Office against suspects and people who want to take care of the letters, such as SKKB. In this case fingerprint is performed on a rolled impression and a plain impression and a column for information along with the identity of the person fingerprints are taken.
\end{abstract}

Keywords: Fingerprints, Investigation Process, Perpetrators, Criminal Acts

\begin{abstract}
Abstrak
Pengambilan sidik jari laten terdapat pada benda-benda ditempat kejadian perkara, setelah benda tersebut dipegang atau diinjak dapat dilakukan dengan dua cara yaitu melalui puder dan proses kimia. Disamping itu pengambilan sidik jari juga dapat dilakukan di Kantor Penyidik terhadap tersangka dan orang-orang yang hendak mengurus surat-surat, seperti SKKB. Dalam hal ini pengambilan sidik jari dilakukan pada sehelai kolom sidik jari yang digulingkan (rolled impression) dan kolom sidik jari yang tidak digulingkan (plain impression) serta kolom untuk informasi beserta identitas orang yang diambil sidik jarinya. Dalam hal pelaku atau tersangka tindak pidana yang belum tertangkap maka sidik jari merupakan salah satu alat bukti fisik yang objektif dalam mengenali kembali serta identifikasipelakunya dengan cara membandingkan sidik jari antara orang yang dicurigai atau sidik jari yang telah tersimpan pada file kepolisian dengan sidik jari laten yang ditemukan dari tempat kejadian perkara (TKP). Penelitian ini menggunakan metode yuidis empiris yang mana yuridis empiris itu sendiri menurut Fred $N$ Kerlner:sebagai pertanyaan-pertanyaan yang dicoba untuk menemukan jawabannya Dapat disimpulkan bahwa penulis ingin melakukan pendekatan terhadapperan sidik jari dalam proses penyidikan bak dari aspek yuridis (peraturan perundang-undangan) maupundalam aspek pelaksanaannya dimasyarakat (kepolisian). Jadi sebagai kesimpulannya pengambilan sidik jari laten terdapat pada bendabenda ditempat kejadian perkara, setelah benda tersebut dipegang atau diinjak dapat dilakukan dengan dua cara yaitu melalui puder dan proses kimia. Disamping itu pengambilan sidik jari juga dapat dilakukan di Kantor Penyidik terhadap tersangka dan
\end{abstract}

* Naskah diterima: 31 Agustus 2017, direvisi: 11 Sebtember 2017, disetujui untuk terbit: 14 Sebtember 2017 
Anny Yuserlina: Peranan Sidik Jari Dalam Proses Penyidikan Untuk Menentukan Pelaku...

orang-orang yang hendak mengurus surat-surat, seperti SKKB. Dalam hal ini pengambilan sidik jari dilakukan pada sehelai kolom sidik jari yang digulingkan (rolled impression) dan kolom sidik jari yang tidak digulingkan (plain impression) serta kolom untuk informasi beserta identitas orang yang diambil sidik jarinya.

Kata kunci: Sidik Jari, Proses Penyidikan, Pelaku, Tindak Pidana

\section{PENDAHULUAN}

Mengungkapkan suatu kejahatan merupakan tugas utana dari instansi kepolisian, sebagai peyidik tunggal dalam perkara pidana umum Indonesia, oleh karena itu penyididk dituntut kerja kerasnya dalam mencari dan menemukan bukti-bukti yang ada hubungannya dengan tindak pidana yang terjadi pada gilirannya pelakunya dapat ditangkap. Maka dalam hal mencari dan mengumpulkan bukti-bukti tersebut, penyidik harus tahu darimana dan bagaimana ia memulai kegiatannya agar mencapai tujuan yang dikehendaki yaitu terungkapnya suatu kejahatan.

Bertitik tolak dari suatu pemikiran bahwa manusia dalam melakukan kegiatan, secara sadar ataupun tidak melakukan perbuatan-perbuatan tersebut ada yang secara nyata yang dapat dilihat dan adapula yang memerlukan teknikteknik pengamatan dengan menggunakan ilmu pengetahuan tertentu yang berguna untuk pengelolaan data lebih lanjut. Dalam hubungannnya dengan suatu tindak pidana yang terjadi maka tempat yang paling dulu dikunjungi atau diolah oleh penyidik adalah tempat dimana tindak pidana itu dilakukan yang disebut dengan TKP. Maka dari tempat inilah penyidik berusaha mengumpulkan buktibukti yang akan dikembangkan lebih lanjut. Sehingga dengan bukti yang diperoleh dari TKP tersebut diharapkan dapat mengungkapkan suatu kejahatan dan menangkap pelakunya.

Salah satu bukti fisik yang umumnya ditemukan pada tempat kejadian perkara adalah sidik jari yaitu bekas tapak jari, telapak tangan, telapak kaki yang tertinggal pada permukaan benda ditempat kejadian perkara, setelah benda itu dipegang atau diinjak. Dengan ditemukan sidik jari pada benda-benda ditempat kejadian perkara akan lebih membantu penyidik Polri dalam melakukan penyidikan, tindak pidana tersebut sebab dalam hal ini ciri-ciri se pelaku kejahatan akan lebih mudah diidentifikasi.

Untuk mendapatkan hasil yang baik melalui identifikasi sidik jari maka diperlukan sekali pengetahuan untuk mengetahui, mengerti dan memahami klarifikasi sidik jari serta keahlian dan pengalaman yang dapat membedakan dan menentukan identik atau tidak sidik jari yang berasal dari sidik jari yang sama. Sidik jari merupakan salah satu bukti fisik yang dapat dianggap sebagai bukti permulaan yang cukup dalam memproses penyidikan yang dapat dipergunakan sebagai sarana identifikasi terhadap orang, sehingga dapat mengetahui dan menentukan identifikasi dari pelaku tindak pidana. Sebab sidik jari merupakan ciri manusia yang bersifat 
tetap, tidak sama dan tidak berubah semenjak dilahirkan sampai ia meninggal dunia atau dengan kata lain sidik jari laten memiliki karakteristik individual artinya bahwa ia tidak sama atau berbeda pada setiap orang malah relative tidak berubah.

Dalam hubungan itu, menurut $\mathrm{R}$. Soesilo ada 4 sistim yang paling ampuh bagi penyidik untuk pengenalan kembali dan mencari identitas penjahat, sehingga lambat laun pelaku atau tersangka dapat diketahui, yaitu:

1. Melalui ciri-ciri manusia yang sedang dicari;

2. Mengenali foto manusia yang sedang dicari dengan disertai keterangan-ketengan tentang ciricirinya;

3. Membandingkan sidik jari orang yang sedang dicari;

4. Modus operandi (cara melakukan kejahatan) dari penjahatnya. ${ }^{1}$

Dalam prakteknya sidik jari, bekas telapak jari tangan, telapak kaki yang tertinggal pada benda itu ditempat kejadian perkara mempunyai tingkat ketelatenan yakni tidak tampak sama sekali sampai yang terlihat jelas seperti bekas telapak jari yang bercampur darah atau yang terdapat pada permukaan yang dilapisi debu tipis. Oleh karena itu sidik jari laten ini mudah sekali rusak atau hilang karena itu perlu diawetkan atau direkam dalam lifter atau foto sehingga dapat dipergunakan sebagai bahan

1 R. Soesilo, 1980, Taktik dan teknik penyidikan perkara kriminal, Politia, Bogor, Hlm. 72 perbandingan atau direkam sebagai barang bukti.

Dengan demikian bahwa sidik jari yang terdapat pada tempat kejadian perkara sangat memegang peranan penting dalam proses pemeriksaan perkara pidana khususnya pada tingkat penyidikan sehingga identitas si pelaku kejahatan tersebut dapat dilacak sekaligus dapat menangkapnya. Walaupun sidik jari merupakan ciri manusia yang tetap dan merupakan sarana identifikasi terhadap manusia bukan berarti setiap tindak pidana yang terjadi terungkap dengan mempergunakan sarana sidik jari ini, bukankah dalam kenyataannya masih banyak tindak pidana yang terjadi belum tertangkap. Hal ini juga disebabkan masih kurangnya kesadaran masyarakat tentang kegunaan sidik jari laten tersebut dalam proses perkara pidana sehingga keaslian sidik jari tersebut tidak terkamin keasliannya sehingga hal ini juga sangat menyulitkan petugas untuk proses penyidikan selanjutnya.

\section{METODE PENELITIAN}

Penelitian ini menggunakan metode yuidis empiris yang mana yuridis empiris itu sendiri menurut Fred $\mathrm{N}$ Kerlner: sebagai pertanyaan-pertanyaan yang dicoba untuk menemukan jawabannya. ${ }^{2}$ Dapat disimpulkan bahwa penulis ingin melakukan pendekatan terhadapperan sidik jari dalam proses penyidikan bak dari aspek yuridis (peraturan perundangundangan) maupundalam aspek

${ }^{2}$ Khuzaifah Dimyati dan Kelk Wardiono, 2008, Metode Peneltian Hukum (buku pegangan kuliah), Surakarta, Hlm. 48 
Anny Yuserlina: Peranan Sidik Jari Dalam Proses Penyidikan Untuk Menentukan Pelaku...

pelaksanaannya dimasyarakat

(kepolisian).

\section{HASIL DAN PEMBAHASAN}

\section{Pengertian Sidik Jari}

Dalam tindak pidana yang terjadi pada umumnya pelaku/tersangka berusaha tidak meninggalkan bekas atau barang-barang bukti di tempat kejadian perkara (TKP), namun tanpa ia sadari (pelaku) sebelumnya telah memegang atau menginjak benda-benda yang ada di tempat kejadian perkara itu yang sudah barang tentu akan meninggalkan bekas telapak tangan atau telapak kakinya. Oleh karena itu salah satu bukti fisik yang umumnya ditinggalkan pelaku/tersangka di tempat kejadian perkaran (TKP) adalah sidik jari laten yaitu bekas tapak jari, telapak tangan, telapak kaki yang terlihat maupun yang tidak terlihat yang tertinggal pada permukaan benda di tempat kejadian perkara, setelah benda itu dipegang atau diinjak.

Sidik jari laten mempunyai karakteristik indoviduil, artinya tidak sama atau berbeda setiap orang dan tidak akan pernah berubah. Karena itu sidik jari laten termasuk bukti fisik yang dapat digunakan untuk mengindentifisir pelaku tindak pidana secara defenitif. Adapun yang dimaksud dengan sidik jari adalah jlhasil reproduksi tapak-tapak jari baik yang sengaja diambil atau dicapkan dengan tinta maupun bekas yang ditinggalkan pada permukaan benda karena pernah disentuh atau dipegang dengan kulit telapak (friction skin) tangan atau kaki.
Yang dimaksud dengan kulit telapak adalah kulit pada bagian telapak tangan mulai dari pangkal pergelangan sampai kesemua ujung jari, dan kulit pada bagian telapak kaki mulai dari tumit sampai kesemua ujung jari, dimana terdapat garis-garis halus yang menonjol keluar, satu sama lainnya dipisahkan dengan celah atau alur dan membentuk lukisan tertentu. Sedangkan kulit telapak terdiri dari dua lapisan, yaitu:

a. Lapisan dermal (kulit jengat) sering dinamakan kulit sebenarnya karena lapisan inilah yang menentukan garisgaris yang terdapat pada permukaan kulit telapak. Apabila lapisan-lapisan dermal terbuka atau cacat akan permanen sifatnya.

b. Lapisan efidermal adalah lapisan kulit luar dimana terdapat garis-garis halus menonjol ke luar yang selanjutnya disebut garis-garis papilair.

Terhadap lukisan-lukisan yang dibentuk oleh garis-garis papilair, inilah ditujukan untuk menentukan pokok perumusan dan perbandingan sidik jari. ${ }^{3}$

\section{Perkembangan Sidik Jari}

Penyidik dalam proses pengungkapan suatu tindak pidana yang salah satu upaya pertamanya adalah melakukan pemeriksaan ditempat kejadian perkara (TKP). Sebab kemungkinan di tempat inilah terdapat bukti-bukti yang mendukung atas tindak pidana tersebut, misalnya sidik jari. Sebab sidik jari merupakan ciri manusia

A. Gumilang, 1993, Kriminalistik Pengetahuan tentang Teknik dan Taktik Penyidikan, Angkasa, Bandung, Hlm. 82 
yang mempunyai sifat individual, artinya tidak sama dengan manusia lainnya. Sebenarnya sidik jari sebagai bukti sudah sejak lama dikenal orang, hal ini terlihat pada zaman India Prasejarah, dimana terdapat lukisan kasar sidik jari pada sebuah batu karang di Nova Scotia. Selain itu, ditemukan pula sidik jari pada tanah liat yang diartikan sebagai segel atau materai dari surat-surat jual beli dari zaman Dynasty Tang pada abad ke 8 masehi. Namun sekalipun ditemui buktibukti peninggalan dari zaman yang lampau, menunjukkan telah adanya kesadaran manusia mengenai bentuk lukisan baris yang terdapat pada permukaan telapak tangan, akan tetapi tidak dapat dipastikan apakah mereka telah memiliki pengetahuan mengenai sidik jari sebagai sarana identifikasi seseorang sebagaimana sekarang ini.

Perkembangan dari pengetahuan manusia dan telah dipertentangkan serta diperbandingkan dengan metode-metode lain. Akhirnya sidik jari diakui juga sebagai metode identifikasi yang tepat, sejak permulaan abad ke XX. Sedangkan perkembangannya dari tahun ke tahun dapat diuraikan sebagai berikut:

a. Tahun 1686, Mercelle Malpighi. Guru besar Anatomi pada Universitas Bologna dengan mempergunakan mikroskop mengamat-ngamati garisgaris tertentu pada permukaan telapak tangan dan mengemukakan bahwa pada ujung jari terdapat garis yang membentuk loop dan spiral akan tetapi Malpighi tidak meneruskan penelitiannya. b. Tahun 1823 Jhon Purkinye, guru besar anatomi Universitas Breslau dalam thesisnya mengemukakan keanekaragaman corak lukisan yang dibentuk oleh jalannya garis-garis papilair itu dengan menggolongkan 9 jenis. Ia juga tidak meneruskan pengamatannya.

c. Tahun 1858, Sir William Herchel pembesar inggris yang ditempatkan di distrik Hoggly begal India adalah orang pertama menggunakan sidik jari secara resmi untuk keperluan yang agak terbatas. Ia mengharuskan kepada penduduk setempat untuk membubuhkan sidik jari (sebagai halnya tanda tangan) pada setiap surat perjanjian dengan tujuan agar pihakpihak yang bersangkutan mematuhi perjanjian dan untuk mencegah terjadinya penipuan atau ketidak jujuran.

d. Tahun 1877, Sembilan tahun kemudian Herchel memperluas lagi penggunaan sidik jari dibeberapa jawatan di Hoggly dan dimulai mempergunakannya sebagai sarana identifikasi terhadap orang hukuman.

e. Tahun 1880 Dr. Henry Faulds pada Tsukiyi Hospital di Tokyo, menulis sebuah karangan yang dimuat dalam majalah nature dan English Scientific Journal, mengemukakan tentang hasil studinya yang menyarankan penggunaan sidik jari untuk keperluan identifikasi dimasa-masa yang akan dating. Ia menganjurkan agar digunakan alat-alat pengambil sidik jari yang dibubuhi dengan tinta seperti pengambilan sidik jari seperti 
Anny Yuserlina: Peranan Sidik Jari Dalam Proses Penyidikan Untuk Menentukan Pelaku...

sekarang ini, lebih jauh dikatakan bahwa sidik jari yang tertinggal ditempat kejadian perkara kejahatan dapat digunakan untuk mengidentifisir pelakunya. Dalam tulisannya itu dipertunjukkan pelaksanaannya mengenai pelaksanaan teori dengan menyertakan gambar sidik jari yang tertinggal dan berasal dari seorang yang telah meminum alkohol dari persediaan laboratorium. Kejadian tersebut merupakan pengenalan kembali untuk yang pertama kalinya terhadap pelaku kejahatan melalui sidik jari late.

f. Tahun 1883 dalam bagian sebauh cerita karya Mark Twin "Life on Mississipi" dilukiskan tentang identifikasi terhadap seseorang pembunuh melalui sidik jari, ibu jari dan sepuluh tahun kemudian (1893) Mark Twin meulis lagi sebuah novel berjudul "pudd'n head Wilson" yang menceritakan kisah pembuktian melaui sidik jari yang berlangsung dalam suatu pengadilan dengan memuat gambar-gambar yang menunjukkan tenatang kepastian hasil dari identifikasi melalui sidik jari itu.

g. Tahun 1981, Juan Vucetich pejabat kepolisian Argentina menyusun file yaitu dokumen yang berguna untuk menyajikan dokumen-dokumen yang berguna untuk menyajikan keterangan serta petunjuk secara sistematis bahan pembuktian yang digunakan dalam pengusutab sampai pada peradilan. ${ }^{4}$

${ }^{4}$ Derson W Bawengan, Teknik Introgasi dan Kasus-kasus Kriminal, Pradnya Paramita, Jakarta, 1979, Hlm. 14
Tetapi Juan Vecetich hanya menyusun bagi seperangkat sisik jari untuk keperluan kepolisian dan sistem Vecetich sampai sekarang masih dipergunakan di Negara-negara berbahasa Spayol.

h. Pada saat sekarang ini di Amerika Serikat setiap bayi yang lahir telah diambil sidik jarinya oleh petugas yang bertujuan untuk menghindari terjadinya penukaran bayi dan pencurian bayi.

\section{Langkah Pengidentifikasian Sidik Jari}

Sebagaimana diketahui pada dasawarsa terakhir ini tingkat kriminalitas menunjukkan grafik peningkatan khusunya pencurian, pemerkosaan dan lain-lain sebagainya.Sehingga aparat penyidik khususnya polri dituntut untuk dapat mengungkapkan setiap tindak pidana yang terjadi. Oleh karenanya petugaspetugas dari reserse kriminal berupaya sedini mungkin untuk mencari, mengumpulkan bukti-bukti serta kemudian menyimpulkan dengan jelas tentang terjadinya suatu tindak pidana, baik melalui ciri-ciri manusia, foto manusia, sidik jari ataupun melihat modus operandi dari pelaku kejahatan. Dalam hal ini tentunya peyidik harus terlebih dahulu melakukan pemeriksaan ditempat kejadian perkara, sebab pada tempat ini biasanya ditemui barangbarang bukti yang dapat mendukung proses penyidikan selanjutnya misalnya saja sidik jari. 
Dalam hal proses pencarian sidik jari seseorang pada tempat kejadian perkara petugas harus memakai sarung tangan atau sapu tangan ketika memegang benda sehingga tidak meninggalkan sidik jarinya sendiri pada benda tersebut. Dalam prakteknya pencarian sidik jari dilakukan pada tempat atau tersangka masuk, objek yang rusak dan bendabenda yang dipindahkan atau dipegang oleh tersangka atau pelaku, sebab disinilah kemungkinan sidik jari si pelaku kejahatan ditemukan dengan jelas. Menurut salah seorang penyidik pembantu di salah satu Polres Bukittinggi menyebutkan bahwa lazimnya sidik jari si pelaku kejahatab ditemukan pada pintu masuk, benda-benda yang dipegang atau dipindahkan yang rusak karena tindak pidana itu, oleh karenanya pencarian sidik jari lebih difokuskan pada objekobjek ini. Adapun peralatan yang dipergunakan minimal:

a. Serbuk sidik jari (puder;

b. Kuas;

c. Pita pengangkat;

d. Gunting;

e. Jepit;

f. Alat penerang atau senter;

g. Kaca pembesar;

h. Kamera (kamera sidik jari) dan film.

Setelah sidik jari ditemukan, maka petugas harus memastikan letak sidik jari laten tersebut pada permukaan guna dikembangkan dan diangkat atau dipindahkan kedalam lifter dengan cara sebagai berikut:

a. Dengan menggunakan senter dari sudut tertentu sidik jari laten pada permukaan benda yang jelas; b. Dengan mendekatkan kepala petugas pada permukaan benda dan melihatnya dari berbagai sudut;

c. Meniup permukaan benda sehingga memberi kelembaban yang memungkinkan sidik jari laten dapat dilihat. 5

Setelah pemberian puder, sidik jari tersebut hendaknya dipotret terlebih dahulu sebelum dipindahkan ke dalam lifter sedangkan benda-benda yang diduga ada sidik jari laten yang dapat diangkat dan dibawa ke kantor untuk diproses lebih lanjut. Sidik jari laten yang ditemui pada tempat kejadian perkara dapat dikembangkan baik dengan puder ataupun dengan bahan kimia.

\section{Pengembangan sidik jari laten dengan puder}

Pengembangan sidik jari dengan puder didasarkan atas daya rekat puder dengan air yang terkandung dalam sidik jari laten tersebut. Puder hanya digunakan untuk mengembangkan sidik jari laten yang terdapat pada permukaan benda yang tidakk menyerap keringat (tidak berpori) seperti kaca, porselin, permukaan yang dipernis/plitur/dicat dan lain-lain. Dalam pengambilan sidik jari laten ini biasanya digunakan puder yang berwarna hitam, abu-abu atau putih. Puder hitam (yang berwarna gelap) digunakan untuk mengembangkan sidik jari laten pada permukaan yang berwarna terang sedangkan puder putih (puder yang berwarna terang) digunakan untuk

5 Juknis Nopol: Juknis/09/V/81 tentang Pencarian sidik jari laten ditempat kejadian tindak pidana, Mabes Polri, 1981, Hlm. 3 
Anny Yuserlina: Peranan Sidik Jari Dalam Proses Penyidikan Untuk Menentukan Pelaku...

mengembangkan sidik jari laten yang berwarna gelap. Cara atau teknik untuk mengembangkan sidik jari laten dengan baik hanya dapat diperoleh melalui praktek dan pengalaman, oleh karena itu harus diperhatikan hal-hal sebagai berikut:

a) Jangan sekali-kali menghadap angin pada waktu akan menggunakan puder;

b) Tuangkan sejumlah kecil puder diatas sehelai kertas;

c) Dengan hati-hati kuas dicelupkan dedalam puder tersebut, kuas diketuk perlahan-lahan dengan jari untuk mengurangi puder yang berlebihan;

d) Puder pada kuas tersebut kemudian dibubuhkan dengan hati-hati pada permukaan yang diduga ada sidik jari laten;

e) Bila sidik jari laten mulai terlihat, gerakkanlah kuas hati-hati sesuai dengan arah garis papiler. Semua puder berlebihan harus disapu dari sidik jari laten tersebut;

f) Bila mungkin sidik jari tersebut dipotret sebelum diangkat atau dipindahkan (lifting);

g) Sidik jari laten yang bercampur dengan darah, debu, atau yang terdapat pada permukaan mentega, permukaan yang dilapisi debu, jangan sekali-kali ditaburi atau dikembangkan dengan puder. Pemberian puder akan merusak sidik jari laten tersebut, karena itu sidik jari yang demikian harus langsung dipotret. $^{6}$

6 Juknis Nopol, 1981, Juknis/09?V/81 tentang Pengembangan Sidik Jari Laten dengan Puderi serta Pemindahannya (Lifting),
Adapun

cara/teknik pengangkatan/pemindahan sidik jari laten sebagai berikut:

1) Pengangkatan dengan pita pengangkat (Lifter) yang tembus mata yang berbentuk roll:

a. Dengan sekali tarik, pita ditarik dari rol dengan panjang secukupnya;

b. Letakkan bagian pita yang berperekat tepat diatas sidik jari laten yang telah diberi puder kemudian ditekan lurus dan kuat dengan jari;

c. Urutlah pita tersebut diatas sidik jari laten yang telah diberi puder dengan gerakan yang rata. Kini sidik jari laten telah beralih kedalam pita tersebut. Urut terus pita tersebut dengan telunjuk supaya sidik jari laten tersebut melekat dengan baik;

d. Tempatkan kartu (alas untuk menempelkan pita) dengan lokasi yang diinginkan;

e. Angkat pita dari permukaan dengan sekali tarik kemudian tempelkan pada kertas (lasa, back ground) tersebut sedemikian rupa sehingga tidak terjadi gelembung udara. Sidik jari laten yang telah terpisah kedalam leter tersebut mempunyai posisi yang sama seperti ketika sidik jari tersebut masih dipermukaan alasnya.

2) Pengangkatan dengan pita, pengangkat yang tak tembus mata (rubber lifter)

Dephankam Markas Besar Polisi Republik Indonesia, Hlm. 3 
a. Pilih jenis rubber lifter tergantung warna puder yang digunakan untuk mengembangkan sidik jari tersebut ( puder putih rubber hitam, puder hitam rubber lifter putih);

b. Guntinglah rubber lifter tersebut sesuai ukuran yang diinginkan, kemudian penutup plastic dibuka;

c. Permukaan rubber lifter yang berperekat diletakkan diatas sidik kari laten yang telah diberi puder tersebut, dan ditekan rata kemudian diurut dengan jari.

d. Angkatlah rubber lifter tersebut dari permukaan dan penutup plastic bening tadi ditempelkan kembali pada rubber lifter (tempat semula). Sidik jari laten yang telah berpindah kedalam rubber lifter tersebut posisinya terbalik atau berlawanan dengan posisi pada benda asal. $^{7}$

Setiap sidik jari laten yang dipindahkan kedalam lifter harus diberikan tanda pengenal atau label (ditulis dalam lifter tersebut) yang memuat keterangan sebagai berikut:

a. Jenis tindak pidana;

b. Tempat kejadian tindak pidana;

c. Tanggal kejadian tindak pidana;

d. Tempat/benda dimana sidik jari ditemukan;

e. Tanggal sidik jari laten dikembangkan;

f. Petugas yang melakukan pengembangan;

g. Skets yang menunjukkan lokasi atau tempat sidik jari laten pada benda.
3) Pengembangan sidik jari laten secara kimia

Pengembangan sidik jari laten secara kimia digunakan pada permukaan benda yang menyerap keringat seperti kertas, karton kayu yang tidak dicat, sebab disini tidak bisa digunakan atau dihapus dari permukaan kertas, sehingga mempengaruhi keaslian suatu dokumen. Pada umumnya ada 3 jenis pengembangan sidik jari secara kimia yaitu:

(1). Dengan yodium (iodine method);

(2). Dengan larutan ninhidryne (Ninhydrin method);

(3). Dengan larutan silver nitrat (silver nitra medthode)

Adapun peralatan yang dipergunakan adalah:

a. Pipa penguap yodium (iodine fuming rife)

1. Pipa kaca yang pada salah satu ujung terdapat slang karet/plastic

2. Isinya tersusun mulai dari ujung ada slang karet, sebagai berikut:

a) Glass wool

b) Calcium clorida (ca ci) lebih kurang 5 gr atau 2,5 $\mathrm{cm}$ panjang

c) Glass wool

d) Kristal yodium lebih kurang 3 gr (1 ampul)

e) Glass wool

Bila tidak ada Glass wool bisa digantikan dengan kapas.

3. Kecil sehingga mudah dibawa ke tempat kejadian tindak pidana

b. Lemari penguap yodium (iodine fuming cabinet)

1. Lemari kecil yang keempat sisinya dari kaca; 
Anny Yuserlina: Peranan Sidik Jari Dalam Proses Penyidikan Untuk Menentukan Pelaku...

2. Pada las lemari ada alat pemanas (lampu,listrik) yang diatasnya terletak sebuah mangkuk Kristal diletakkan;

3. Sisi atas lemari dapat dibuka dan ditutup serta ada tempat gantungan kertas;

4. Tidak biasa dibawa ketempat kejadian tindak pidana (digunakan di kantor). ${ }^{8}$

Adapun pengembangan sidik jari laten secara kimia dengan menggunakan yodium, ada dua cara yaitu:

a. Dengan menggunakan pipa penguap yodium

1. Setelah pipa diisi sesuai dengan susunan tersebut diatas, ujung pipa ditempatkan diatas permukaan yang diduga ada sidik jari laten lebih kurang $2 \mathrm{~cm}$;

2. Melalui slang karet/plastik, hembuskanlah udara kedalam pipa tersebut. Udara kering/panas dari hembusan itu menyebabkan Kristal yodium menguap. Untuk mempercepat penguapan bagian pipa tepat dimana Kristal yodium tersebut digenggam dengan tangan atau dibakar dengan korek api;

3. Gerakan ujung pipa dimana pipa yodium keluar permukaan benda. Sidik jari laten akan timbul warna coklat kekuning-kuningan;

4. Bila sidik jari laten tersebut telah cukup kontras segeralah dipotret karena ia akan berangsur-angsur hilang;

8 Juknis/ 11/v/81 tentang Pengembangan Sidik JAri Laten secara Kimia, Dephankam Mabes Polri, 1981, Hlm. 3
5. Sisa kristal yodium masih dapat dipakai lagi asal sesudah dipakai segera dituangkan kembali dalam botol kristal yodium dan ditutup rapat-rapat.

b. Dengan menggunakan lemari penguap yodium

1. Tuangkanlah kristal yodium kedalam mangkok;

2. Letakkanlah mangkok tersebut diatas alat pemanas (lampu, alat pemanas yang menggunakan listrik);

3. Setelah kristal yodium tersebut menguap dan memenuhi seluruh ruangan lemari, gantunglah kertas, dokumen yang diduga ada sidik jari laten dalam lemari tersebut;

4. Sidik jari laten akan timbul dalam warna coklat kekuning-kuningan dan bila telah cukup kontras, kertas dokumen tersebut dikeluarkan dan potretlah sidik jari laten tersebut.

Kemudian pengembangan sidik jari laten dengan larutan ninhydrin dengan asam amino yang terkandung dalam sidik jari laten. Peralatan yang diperlukan:

1. Alat/bahan untuk membuat larutan:

a. Tabung pengukur;

b. Baskom/true;

c. Kristal/serbuk ninhydrin;

d. Aceton.

2. Sarung tangan/pinset;

3. Kuas besar (yang biasa digunakan untuk mengecat);

4. Alat pemanas (ovent lebih kurang $1000^{\circ} \mathrm{c}$ atau kertas tersebut disetrika dengan setrika listrik). 
Cara atau teknik pengembangan:

a. Kertas atau dokumen yang diduga ada sidik jari laten dicelupkan atau direndam dalam larutan (dapat juga disemprot atau dioleskan memakai kuas);

b. Setelah seluruh permukaan basah terkena larutan, kertas tersebut dikeluarkan dari dalam larutan;

c. Kertas tersebut dianginkan dalam ruangan yang cukup ventilasinya. Sidik jari laten akan muncul dalam warna coklat merah kekuningkuningan selama kira-kira 1 atau 2 jam atau bahkan 24 jam kemudian;

d. Untuk mempercepat munculnya sidik jari laten tersebut langkah berikut ini dapat digunakan:

1. Setelah kertas dikeluarkan dari dalam larutan kemudian dianginkan dengan mempergunakan dryer.

2. Setelah permukaan kertas tersebut kering, kertas tersebut dimasukkan kedalam ovent \pm $100^{\circ} \mathrm{c}$ atau kertas tersebut disetrika dengan setrika listrik.

e. Bila sidik jari laten yang timbul telah cukup kontras, segera dipotret sebelum ia berangsur hilang.

Selanjutnya pengembangan sidik jari laten dengan menggunakan larutan silver nitrat. Hal ini didasarkan atas reaksi kimia antara larutan silver nitrat dengan garam yang terkandung dalam sidik jari laten:

a. Alat bahan untuk membuat larutan:

1. Tabung pengukur;

2. Baskom dari email/tray;

3. Kristal atau serbuk silver nitrat;
4. Air suling (aquades);

b. Sarung tangan/pinset;

c. Kuas besar (yang biasa digunakan untuk mengecat)

d. Lampu berkekuatan 1000 watt (lampu pemotretan)

Adapun cara teknik pengembangan:

1. Dengan menggunakan kuas, larutan dioleskan pada permukaan kertas atau objek yang dicurigai ada sidik jari laten. Gerakan kuas searah dan sekali jalan;

2. Setelah seluruh permukaan kertas atau objek dioleskan dengan larutan pada kertas tersebut dibiarkan kering sendiri (untuk mempercepat pengeringan dapat digunakan hair dryer);

3. Permukaan kertas atau objek tersebut kemudian disinari dengan cahaya atau dengan lampu berkekuatan +1000 watt (lampu pemotretan). Sidik jari laten akan muncul dalam warna coklat kemerah-merahan.

4. Bila sidik jari tersebut telah cukup kontras segera dijauhkan dari sinar atau cahaya dan segera dipotret jika tidak sidik jari tersebut menjadi hilang.

Teknik atau cara pengambilan sidik jari:

1. Tuangkan sejumlah tinta daktiloskopi diatas plat kaca. Ratakan tinta tersebut dengan roller yang digerakkan maju mundur diusahakan tidak terlalu tebal.

2. Blanko sidik jari diberikan pada orang yang hendak diambil sidik jarinya untuk ditulis nama serta keterangan yang diperlukan. 
Anny Yuserlina: Peranan Sidik Jari Dalam Proses Penyidikan Untuk Menentukan Pelaku...

Kemudian petugas mengisi data sinyalemen orang yang bersangkutan, menulis tanggal pengambilan dan nama serta tandatanda dikolom yang tersedia.

3. Tempatkan kartu sidik jari pada penjepit kartu sidik jari sedemikian rupa sehingga kolom untuk jari dan tangan yang digulingkan siap untuk dipakai;

4. Pegang tangan orang yang bersangkutan dan minta kepadanya untuk berdiri disebelah kanan kemudian dilihat jari-jari tangannya jika basah karena keringat keringkan dahulu demikian juga bila jari-jari tersebut kotor.

5. Mintalah orang tersebut bersikap santai. Peganglah ibu jari tangan yang bersangkutan, gulingkan jari tersebut dari sisi kuku yang satu ke kuku yang lain. Demikian dilakukan untuk jari secara keseluruhan.

6. Gulingkan jari-jari tersebut satu kali saja pada kartu sidik jari sesuai dengan kolomnya masing-masing.

7. Geser kartu sidik jari sedemikian rupa sehingga kolom jari-jari tangan siap untuk digunakan. Berilah tanda lagi pada plat kaca atau ratakan kembali tinta dengan roller jika perlu.

8. Mintalah orang yang bersangkutan untuk berdiri disebelah kanan untuk pengambilan sidik jari kiri.

9. Geserlah kartu sidik jari sedemikian rupa sehingga kolom untuk plain impression, yaitu sidik jari yang tidak digulingkan siap untuk digunakan.
10. Mintalah orang yang bersangkutan untuk meluruskan empat jari tangan kanannya, pegang jari tangan orang tersebut dan tekankan langsung pada tinta dan kemudian angkat dan ulangi prosedur yang sama pada kolom yang telah tersedia pada kartu sidik jari. Lakukan prosedur ini juga pada ibu jari tangan kanan yang bersangkutan.

11. Lakukan prosedur diatas (10) untuk keempat jari tangan kiri dan ibu jari tangan kiri.

12. Berikan pada orang-orang yang bersangkutan alat pembersih tangan seperti ink cleaner, bensin atau sabun dan lap kain.

13. Angkatlah kartu sidik jari tersebut dan buatlah catatan mengenai adanya jari-jari yang bunting atau rusak jika memang ada. ${ }^{9}$

\section{Peranan Sidik Jari Dalam Menemukan Pelaku Tindak Pidana}

Dalam tempat kejadian tindak pidana selalu ditemukan barang bukti yang dapat mendukung proses penyidikan perkara tersebut, kecuali sidik jari si pelaku. Oleh karena itu salah satu bukti fisik yang umumnya dijumpai ditempat kejadian perkara adalah sidik jari laten. Yaitu bekas tapak jari, telapak tangan, telapak kaki yang tertinggal pada permukaan benda ditempat kejadian perkara setelah benda itu dipegang atau diinjak.

Oleh karena itu pada prinsipnya keberhasilan mengungkapkan tindak

${ }^{9}$ Zwinglimanu,dkk, Penuntun Daktiloskopi, Sub Direktorat Identifikasi Direktorat Reserse Polri, 1984, Hml. 67-68 
pidana dominan ditemukan ditempat kejadian perkara yaitu melalui pengolahan tempat kejadian perkara dilakukan dengan maksud mencari, mengumpulkan dan menganalisa petunjuk-petunjuk atau keterangan barang bukti serta identitas tersangka.

Menurut salah seorang penyidik dimana umumnya tindak pidana yang terjadi dilakukan pengambilan sidik jari dari benda-benda yang terdapat dilokasi kejadian yang kemudian dikembangkan sehingga dapat ditentukan siapa pemiliknya yang pada gilirannya pelaku atau tersangka dapat ditangkap.

Berita acara pemeriksaan sidik jari hanya boleh diberikan kepada hakim untuk keperluan pengadilan, penuntutan dan kepolisian. Syarat-syarat berita acara pemeriksaan sidik jari adalah:

a. Syarat formil terdiri dari:

1) Dibuat oleh orang yang berwenang;

2) Diberi tanggal dan nomor;

3) Dibuat sekurang-kurangnya dua (2) orang yang masing-masing membubuhkan tanda tangan;

4) Dibuat atas sumpah jabatan;

5) Diketahui/disyahkan oleh pimpinan.

b. Syarat materil terdiri dari:

1) Membuat keterangan tentang jalannya pemeriksaan;

2) Melampirkan keterangan reproduksi dari sidik jari yang diperbandingkan dalam ukuran asli (1:1) dan yang sudah diperbesar lengkap dengan nomor urut untuk titik persamaan.
Kemudian setelah sidik jari diambil akan dibandingkan dengan sidik jari:

1. Orang-orang yang dicurigai yang ada hubungannya dengan tindak pidana yang terjadi;

2. Pelaku atau tersangka tindak pidana yang telah diambil sidik jari.

Hasil perbandingan sidik jari inilah yang akan menentukan dan membantu penyidik dalam mengungkapkan siapa pelaku tindak pidana yang terjadi. Karena pada dasarnya, sidik jari mempunyai karakteristik individual artinya dia tidak sama atau berbeda setiap orang dan malah relative tidak berubah.

\section{KESIMPULAN}

Dari pembahasan yang telah diuraikan diatas maka dapat kita simpulkan sebagai berikut:

1. Pengambilan sidik jari laten terdapat pada benda-benda ditempat kejadian perkara, setelah benda tersebut dipegang atau diinjak dapat dilakukan dengan dua cara yaitu melalui puder dan proses kimia. Disamping itu pengambilan sidik jari juga dapat dilakukan di Kantor Penyidik terhadap tersangka dan orang-orang yang hendak mengurus surat-surat, seperti SKKB. Dalam hal ini pengambilan sidik jari dilakukan pada sehelai kolom sidik jari yang digulingkan (rolled impression) dan kolom sidik jari yang tidak digulingkan (plain impression) serta kolom untuk informasi beserta identitas orang yang diambil sidik jarinya.

2. Dalam hal pelaku atau tersangka tindak pidana yang belum tertangkap 
Anny Yuserlina: Peranan Sidik Jari Dalam Proses Penyidikan Untuk Menentukan Pelaku...

maka sidik jari merupakan salah satu alat bukti fisik yang objektif dalam mengenali kembali serta identifikasipelakunya dengan cara membandingkan sidik jari antara orang yang dicurigai atau sidik jari yang telah tersimpan pada file kepolisian dengan sidik jari laten yang ditemukan dari tempat kejadian perkara (TKP).

\section{SARAN}

Berdasarkan kesimpulan maka beberapa saran yang diberikan dan diajukan dalam penelitian ini adalah sebagai berikut:

1. Sebaiknya dalam pengambilan sidik jari laten terhadap benda-benda yang berada disekitar TKP harus dimuat dalam laporan yang tercatat dan terinci sehingga menemukan titik temu dari perkara yang terjadi. Dan pegambilan sidik jari untuk pembuatan surat-surat seperti SKKB sebagainya ada Rekam Sidik Secara tekhnologi terbaru.

2. Sebaiknya untuk mengetahui pelaku atau tersangka tindak pidana yang belum tertangkap dilakukan sidik jari laten terhadap semua objek yang ditemukan dari tempat kejadian perkara (TKP).

\section{UCAPAN TERIMAKASIH}

Puji dan Syukur penulis ucapkan ke hadirat Allah SWT yang telah memberikan Rahmat dan Karunia-Nya, sehingga akhirnya penulis dapat menyelesaikan penulisan karya ilmiah ini yang berjudul: PERANAN SIDIK JARI
DALAM PROSES PENYIDIKAN UNTUK MENENTUKAN PELAKU TINDAK PIDANA .

Penulis menyadari bahwa tanpa bantuan dan dorongan dari berbagai pihak tidak mungkin karya ilmiah ini dapat diselesaikan. Oleh karena itu pada kesempatan ini dengan segala kerendahan hati, penulis ingin mengucapkan terimakasih dan penghargaan yang sebesar-besarnya kepada:

1. Bapak Dr.Eviandi Ibrahim S.H., M.Hum selaku Ketua Sekolah Tinggi Ilmu Hukum Putri Maharaja Payakumbuh

2. Seluruh rekan-rekan Dosen Sekolah Tinggi Ilmu Hukum Putri Maharaja yang tidak dapat penulis sebutkan satu-persatu.

\section{DAFTAR PUSTAKA}

R. Soesilo, Taktik dan teknik penyidikan perkara kriminal, Politia, Bogor, 1980.

A. Gumilang, Kriminalistik Pengetahuan tentang Teknik dan Taktik Penyidikan, angkasa Bandung, 1993.

Derson W Bawengan, Teknik Introgasi dan Kasus-kasus Kriminal, Pradnya Paramita, Jakarta, 1979.

Juknis Nopol: Juknis/09/V/81 tentang Pencarian sidik jari laten ditempat kejadian tindak pidana, Mabes Polri, 1981.

Juknis Nopol: Juknis/09?V/81 tentang Pengembangan Sidik Jari Laten dengan Puderi serta Pemindahannya (Lifting), Dephankam Markas Besar Polisi Republik Indonesia, 1981 
Jurnal Cendekia Hukum: Vol. 3, No 1, September 2017

Juknis/ 11/v/81 tentang Pengembangan

Sidik Jari Laten secara Kimia, Dephankam Mabes Polri, 1981.

Zwinglimanu,dkk, Penuntun

Daktiloskopi, Sub Direktorat

Identifikasi Direktorat Reserse

Polri, 1984. 